\title{
Sleep Problems in Turkish Children with Conduct Disorder: A Single-centre, Cross-sectional, Case-control Study
}

\section{Davranım Bozukluğu Olan Türk Çocuklarında Uyku Sorunları: Tek-merkezli, Kesitsel, Olgu-kontrol Çalıșması}

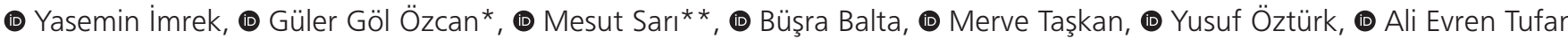 \\ Bolu Abant lzzet Baysal University Faculty of Medicine, Department of Child and Adolescent Psychiatry, Bolu, Turkey \\ *Bilecik State Hospital, Clinic of Child and Adolescent Psychiatry, Bilecik, Turkey \\ * University of Health Sciences Turkey, Başakşehir Çam and Sakura City Hospital, Clinic of Child and Adolescent Psychiatry, Istanbul, Turkey
}

\begin{abstract}
Objective: This study aimed to determine the sleep habits and sleep problems of patients with conduct disorder (CD) and to compare them with healthy controls.

Materials and Methods: This cross-sectional study included 45 children diagnosed with $C D$ and 50 healthy controls. Sleep was evaluated by children's sleep habits questionnaire (CSHQ). Qualitative variables between groups were compared using chi-square test, whereas quantitative variables were compared using t-test. Correlation analyses were conducted to evaluate relationships between the quantitative variables. Linear regression analysis was conducted to evaluate the predictors of severity of $C D$ symptoms. $P$ was set at 0.05 .

Results: The average ages of children in $C D$ and control groups were $11.04 \pm 1.20$ and $10.00 \pm 1.55$ years, respectively. Moreover, $71.1 \%$ in the $\mathrm{CD}$ group were boys (vs. $78.0 \%$ in the control group). The groups were comparable in terms of socio-demographic features (all $p>0.05$ ). Scores of all CSHQ subscales were significantly elevated in the CD group compared with the control group $(p<0.001)$. Clinically significant sleep problems were significantly elevated in the CD group $(p<0.001)$. In the regression analysis, bedtime resistance and daytime sleepiness emerged as significant predictors of the severity of CD.

Conclusion: Sleep problems may be common among Turkish children with $C D$, and bedtime resistance and daytime sleepiness may indicate severity of symptoms. Multimodal treatment for CD among children may address sleep problems.
\end{abstract}

Keywords: Conduct disorder, sleep habits, child
Öz

Amaç: Çalışmamızın amacı, davranım bozukluğu (DB) olan hastaların uyku alışkanlıklarını ve uyku sorunlarını belirlemek ve bunları sağlıklı kontrollerle karşılaştırmaktır.

Gereç ve Yöntem: Bu çalışma, sağlıklı bir kontrol grubu ile kesitsel bir çalışmadır. DB tanısı alan 45 çocuk ve 50 sağlıklı kontrol çalışmaya dahil edildi. Uyku alışkanlıkları, çocukların uyku alıskanlıkları anketi (CUAA) ile değerlendirildi. Gruplar arası nitel değişkenler ki-kare testi ile kantitatif değişkenler t-testi ile karşılaştıııldı. Nicel değiş̧kenler arasındaki ilișkileri değerlendirmek için korelasyon analizleri yapılmışır. DB semptomlarının şiddetini belirleyen faktörleri değerlendirmek için doğrusal regresyon analizi yapılmıştır. $P<0,05$ değeri istatistiksel olarak anlamlı kabul edildi. Bulgular: DB'li çocukların ve kontrollerin ortalama yaşları sırasıyla $11,04 \pm 1,20$ ve $10,00 \pm 1,55$ yıldı. DB'li çocukların \%71,1'ini erkekler oluşturmuştur (kontrollerin \%78,0'i). Gruplar sosyo-demografik özellikler açısından benzerdi $(p>0,05)$. Tüm ÇUAA alt ölçeklerinin puanları, kontrollere kıyasla DB grubunda anlamlı olarak yüksekti $(p<0,001)$. DB'li hastalarda klinik olarak anlamlı uyku problemleri daha yüksekti $(p<0,001)$. Regresyon analizinde, yatma zamanı direnci ve gündüz uykululuğu davranış bozukluğunun şiddetinin anlamlı yordayıcıları olarak ortaya çıktı.

Sonuç: DB'si olan Türk çocuklarında uyku sorunları yaygın olabilir ve yatma zamanı direnci ve gündüz uykululuk semptomların şiddetini gösterebilir. Çocuklarda DB için çok boyutlu tedavi uyku problemlerini de ele almalıdır.

Anahtar Kelimeler: Davranım bozukluğu, uyku alışkanlıkları, çocuklar

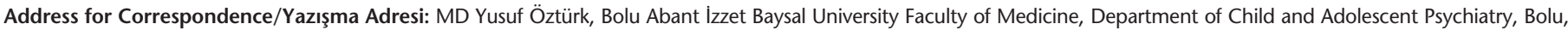
Turkey

Phone: +90 3742752525 E-mail: yusuf26es@hotmail.com ORCID-ID: orcid.org/0000-0002-3412-9879

Received/Gelis Tarihi: 18.12.2020 Accepted/Kabul Tarihi: 08.03.2021

${ }^{\circ}$ Copyright 2021 by Turkish Sleep Medicine Society / Journal of Turkish Sleep Medicine published by Galenos Publishing House. 


\section{Introduction}

Conduct disorder (CD) is defined as a repetitive and persistent pattern of violation of basic rights of others and/or major age-appropriate norms and rules of society as indicated by aggression to people and animals, destruction of property, deceitfulness/theft and delinquency/truancy (1). It often arises in childhood or adolescence (2) and the prevalence of CD may vary between $1.0-16.0 \%$ in childhood (1). The etiology is considered to be multi-factorial with a genetic predisposition interacting with environmental stressors (2). The risk may be higher among disadvantaged families and children with CD may be involved frequently in legal, health and social welfare services (3). Diagnostic and Statistical Manual of Mental Disorders-fifth edition (DSM-5) denotes a more malign subtype with symptoms appearing before the age of 10 while the more benign adolescent-onset subtype is defined with emergence of symptoms after 10 years of age (1). However, the importance of this criterion as well as the similar criterion of limited prosocial emotions are being currently debated (4).

Sleep is a periodic, reversible reduction of awareness and responsivity to environmental stimuli which is critical for brain development (5). Sleep problems may be common especially among young children and may affect up to $20.0 \%$ (6). Sleep problems display complex, bidirectional relationships with various pediatric psychopathologies and their rates in children with psychiatric disorders may be elevated (7). Especially, bed-time resistance, problems in falling and sustaining sleep, parasomnias and daytime sleepiness and fatigue may be common among children with psychiatric disorder (8). The relationships between sleep problems and psychopathology may be due to symptoms of psychopathology, problems in family functioning, parenting style, sleep practices, psychopathology among parents or negative life events $(6,8)$.

Sleep problems have also been reported to be elevated among children with disruptive behavior disorders, including CD (9-11). Reduced sleep duration and quality have also been found to be associated with elevated levels of aggression, impulsivity, peer bullying and victimization (12-14). The relationships between sleep problems and delinquency may be independent of psychopathic symptoms and parenting practices (15). The relative importance of attention deficit and hyperactivity disorder (ADHD) comorbidity and effects of treatment on sleep problems among children with CD is still being debated (10). Therefore; the primary aims of this study were;

a) To determine sleep habits and sleep problems of patients who were followed up in our clinic with the diagnosis of $C D$,

b) To compare sleep habits and sleep problems of patients with $\mathrm{CD}$ and healthy controls and,

c) To evaluate the effect of comorbid ADHD diagnosis on sleep problems among children with CD.

\section{Materials and Methods}

\section{Study Design, Date, Setting and Ethical Issues}

The study was conducted between February and May 2020. Ethics committee approval was granted for the study from Bolu
Abant İzzet Baysal University Clinical Trials Ethics Committee (IRB date: 16.03.2020, no: 118). Verbal and written consents of the mothers and their children who participated in the study were obtained prior to study entry. All study procedures were conducted following the Declaration of Helsinki and local laws and regulations.

\section{Participants}

The inclusion criteria for the CD group were age 8 between 12 years, CD diagnosis according to the DSM-5 criteria and interviews according to the schedule for affective disorders and schizophrenia for school age adolescents present and lifetime version-Turkish version (K-SADS-PL), being treatment naive, lack of comorbidity except ADHD and Oppositional Defiant Disorder (ODD), lack of chronic medical/neurologic conditions requiring treatment (i.e. epilepsy, diabetes etc.), and providing informed consent for study participation.

The exclusion criteria included anxiety disorders, drug/ alcohol abuse, bipolar disorder, major depressive disorder, obsessive-compulsive disorder, post-traumatic stress disorder, intellectual disability, psychotic symptoms and major known medical disorders of the central nervous system (e.g. epilepsy). Intellectual disability was excluded according to developmental and academic history and clinical evaluations.

The same child psychiatrist interviewed both children and their mothers. The potential participants included 118 children applying our clinic with CD symptoms within the study period. We excluded children who were not diagnosed with $C D$ $(n=24)$ and those refusing participation $(n=6)$ and evaluated 88 children with CD. Thirty-six of 88 children had comorbid psychiatric disorders (intellectual disability $=12$; major depressive disorder=7; anxiety disorders $=10$; bipolar spectrum disorder $\mathrm{n}=4$; obsessive-compulsive disorder $=2$; post-traumatic stress disorder=1). Seven children with missing data were also excluded from the study leading to 45 treatment-naive children with CD aged 8-12 years in the patient group.

The control group consisted of children between 8 and 12 years of age who came to the pediatric clinic of the hospital for wellchild visits. Pediatrics clinics are a free and routine service in our country, and children come to this clinic from the general population. Pediatricians identified children 8-12 years old and asked the parents for potential participation. Exclusion criteria for the healthy control group were; children diagnosed with a psychiatric disorder and those receiving psychopharmacological treatments, children with chronic medical and neurological disorders or those with a past history of psychiatric treatment. During the study period, 54 healthy children applied to the study center and four of them refused participation in the study. As a result, 50 children were included in the control group.

\section{Data Collection}

Socio-demographic data form: We created this form to collect information about the socio-demographic characteristics of children and parents. The form includes questions about the child's age, gender, family's socio-economic level, academic status and peer relationships of the child, and parents' age, educational, marital and vocational status. Academic success was evaluated according to the latest report cards from school 
while we depended on children's reports for peer relationships. The clinicians completed the form.

K-SADS-PL: This is a semi-structured interview developed to investigate current and lifetime psychopathology in children and adolescents aged 6 to 18 years. K-SADS-PL was created according to DSM-5 (American Psychiatric Association, 1994) diagnostic criteria (16). Turkish translation and its validity and reliability study was conducted by Gökler and colleagues (17). DSM-5 based screening and assessment scale for disruptive behavior disorders parent form (DBSAS-DBD): This form evaluates symptoms of inattention, hyperactivity/impulsivity, oppositionality and, CDs as per DSM-5 criteria. Each item (9 for attention deficit, 6 for hyperactivity, 3 for impulsivity, 8 for oppositional defiant disorder, and 15 for $C D$ ) is rated on a three-point likert-type scale ( $0=$ none, $1=$ occasionally, $2=$ much, and $3=$ very much). When subscales are evaluated, 2 to 3 points per item are assessed as symptomatic (1), while 0 to 1 are assessed as non-symptomatic (18). The validity and reliability study of this scale was established previously (19).

Children's sleep habits questionnaire (CSHQ)-short form: This form was used to evaluate sleep habits and problems in children and a total CSHQ score of 41 has been reported to be a sensitive cut-off for clinically significant sleep problems (20). It determines the need for further investigation by reviewing general sleep problems rather than making a specific diagnosis. Parents are asked to evaluate the child's sleep habits over the previous week. Parents completed the Turkish version of CSHQ at baseline in this study (21).

\section{Statistical Analysis}

We used the Statistical Program for Social Sciences (SPSS 22.0, IBM Inc., Armonk, NY) program for statistical analysis.
The socio-demographic and clinical categorical variables were reported as counts and frequencies. Chi-square test was used to compare categorical variables across groups. Assumptions of normality were tested with the Kolmogorov-Smirnov test. Quantitative variables were compared across groups with t-test due to normality. Pearson correlation analysis was used to determine the correlation between continuous variables. We performed linear regression analysis to evaluate which sleep problem predicted behavioral problems. P-value was accepted as $<0.05$ (two-tailed).

\section{Results}

Within the study period, 45 children with CD and 50 healthy control children were enrolled. The groups did not differ significantly in terms of children's age, gender and maternal age. Maternal education levels and occupation differed significantly across groups $(p=0.003, p=0.040$, respectively). Children with $C D$ reported greater academic and peer problems compared to controls ( $p<0.001, p<0.001$, respectively) (Table 1 ).

Comparison of CD and control groups in terms of CSHQ and DBSAS-DBD was shown in Table 2 and Table 3. According to the cut-off score of $41,66.7 \%(n=30)$ of the children with CD group had clinically significant sleep problems while this rate was $16.0 \%(n=8)$ in healthy control children. The rate of clinically important sleep problems was significantly elevated among the CD group $(p<0.001)$ (Table 4$)$. The diagnosis of $\mathrm{CD}$ increased the odds of significant sleep problems 10.5 times (95\% confidence interval=4.0-27.9, $\mathrm{p}<0.05$ ). Among children with CD, 21 had comorbid ADHD (46.7\%). Children with ADHD comorbid with CD displayed significantly elevated levels of sleep anxiety compared to children with CD only (Table 4).

\begin{tabular}{|c|c|c|c|}
\hline & $C D(n=45)$ & Control $(n=50)$ & $\mathbf{p}$ \\
\hline Age $^{*}($ mean $\pm S D)$ & $11.04 \pm 1.20$ & $10.00 \pm 1.55$ & 0.104 \\
\hline Female & $13(28.9 \%)$ & $11(22 \%)$ & \multirow{2}{*}{0.485} \\
\hline Male & $32(71.1 \%)$ & $39(78 \%)$ & \\
\hline Maternal age* $($ mean $\pm S D)$ & $38.24 \pm 7.68$ & $37.10 \pm 6.53$ & 0.445 \\
\hline$<8$ years & $39(86.7 \%)$ & $29(58 \%)$ & \multirow{2}{*}{0.003} \\
\hline$>8$ years & $6(13.3 \%)$ & $21(42 \%)$ & \\
\hline \multicolumn{4}{|l|}{ Maternal working status $\mathbf{n}(\%)$} \\
\hline Housewife & $35(77.8 \%)$ & $29(58 \%)$ & \multirow{2}{*}{0.040} \\
\hline Working & $10(22.2 \%)$ & $21(42 \%)$ & \\
\hline Bad & $22(48.9 \%)$ & $12(24 \%)$ & $<0.001$ \\
\hline \multicolumn{4}{|l|}{ Peer relation ${ }^{* *} \mathrm{n}(\%)$} \\
\hline Good & $8(17.8 \%)$ & $48(96 \%)$ & \multirow{2}{*}{$<0.001$} \\
\hline Bad & $37(82.2 \%)$ & $2(4 \%)$ & \\
\hline
\end{tabular}


There was a positive statistically significant correlation between DBSAS-DBD CD subscale and all subscales of the CSHQ (bed-time resistance: $r=0.586, p<0.001$; sleep latency: $r=0.375, p<0.001$; sleep duration: $r=0.291, p=0.007$; sleep anxiety: $r=0.420, p<0.001$; night waking: $r=0.337, p=0.002$; parasomnia: $r=0.400, p<0.001$; sleep-disordered breathing: $r=0.219, p=0.443$; daytime sleepiness: $r=0.526, p<0.001$ ).

Lastly, we performed a linear regression analysis to evaluate the predictive value of sleep problem domains in CD severity. In this analysis only the bed-time resistance and daytime sleepiness emerged as significant predictors of DBSAS-DBD CD scores (Table 5).

\section{Discussion}

This single-center, cross-sectional, case-control study aimed to compare sleep habits and problems between children with $C D$ and healthy controls and to evaluate the effects of comorbid ADHD on sleep problems. We found that treatment-naive children with $C D$ had significantly elevated sleep problems compared to control children and that the presence of comorbid ADHD significantly elevated sleep anxiety among children with $C D$. Bed-time resistance and daytime sleepiness emerged as the only significant predictors of $C D$ severity.

The main finding of our study is that children with CD display elevated levels of sleep problems compared to healthy controls. The association between disruptive behavior disorders and sleep problems is complex $(13,22)$. Both reduced sleep quantity and quality have been found to be associated with externalizing disorders such as $C D(10,11)$. This relationship seems to be bidirectional and complex (23) and seems to emerge by early childhood (11). According to some studies severity of oppositional and conduct symptoms may correlate with sleep problems (11). Our findings are in agreement with previous work demonstrating that conduct problems are associated with global reports of sleep problems.

Another finding of our study was elevated levels of sleep anxiety in children with $A D H D$ and $C D$ compared to those with $C D$ alone. Although it is known that comorbidity among various

\begin{tabular}{|l|l|l|l|l|}
\hline Table 2. Comparison of children with CD and control children in terms of sleep habits & \multicolumn{1}{l|}{} \\
\hline & $\mathrm{CD}(\mathbf{n}=\mathbf{4 5})$ & Control $(\mathbf{n}=\mathbf{5 0})$ & $\mathbf{t}$ & $\mathbf{p}$ \\
\hline Bedtime resistance & $10.77 \pm 3.15$ & $6.10 \pm 1.3$ & 10.429 & $<\mathbf{0 . 0 0 1}$ \\
\hline Sleep latency & $1.82 \pm 0.90$ & $1.10 \pm 0.30$ & 5.333 & $<0.001$ \\
\hline Sleep duration & $4.59 \pm 1.77$ & $3.22 \pm 1.01$ & 5.316 & $<0.001$ \\
\hline Sleep anxiety & $6.34 \pm 1.52$ & $4.20 \pm 0.45$ & 8.650 & $<0.001$ \\
\hline Night waking & $4.77 \pm 1.58$ & $3.22 \pm 0.42$ & 6.681 & $\mathbf{0 . 0 0 1}$ \\
\hline Parasomnias & $10.32 \pm 2.80$ & $7.16 \pm 1.67$ & 7.898 & $\mathbf{0 . 0 0 4}$ \\
\hline Sleep disordered breathing & $3.89 \pm 1.51$ & $3.25 \pm 1.45$ & 2.701 & 0.146 \\
\hline Daytime sleepiness & $14.59 \pm 4.11$ & $10.06 \pm 2.31$ & 11.236 & $<\mathbf{0 . 0 0 1}$ \\
\hline CD: Conduct disorder & & & \\
\hline
\end{tabular}

Table 3. Comparison of CD and control group in terms of DSM-5 based screening and assesment scale for disruptive behavior disorders parent form scores

\begin{tabular}{|l|l|l|l|l|}
\hline & $\mathrm{CD}(\mathrm{n}=\mathbf{4 5})$ & Control $(\mathrm{n}=5 \mathbf{5 0})$ & $\mathbf{t}$ & $\mathbf{p}$ \\
\hline DBSAS-DBD-AD & $4.23 \pm 3.13$ & $1.50 \pm 1.47$ & 5.091 & $<0.001$ \\
\hline DBSAS-DBD-HA & $3.22 \pm 3.00$ & $1.48 \pm 1.45$ & 3.251 & 0.002 \\
\hline DBSAS-DBD-ODD & $2.70 \pm 2.67$ & $1.72 \pm 1.26$ & 2.077 & 0.043 \\
\hline DBSAS-DBD-CD & $3.95 \pm 2.40$ & $0.44 \pm 0.79$ & 8.542 & $<0.001$ \\
\hline
\end{tabular}

DBSAS-DBD: DSM-5 based screening and assesment scale for disruptive behavior disorders parent form, AD: Attention deficit, HA: Hyperactivity, ODD: Oppositional defiant disorder, $C D$ : Conduct disorder

\begin{tabular}{|c|c|c|c|c|}
\hline & No comorbidity $(\mathrm{n}=\mathbf{2 4})$ & Comorbid ADHD $(n=21)$ & $\mathbf{t}$ & $\mathbf{p}$ \\
\hline Bedtime resistance & $10.08 \pm 2.81$ & $11.61 \pm 3.40$ & -1.618 & 0.113 \\
\hline Sleep duration & $4.92 \pm 1.77$ & $4.21 \pm 1.74$ & 1.350 & 0.184 \\
\hline Sleep anxiety & $6.54 \pm 2.17$ & $8.32 \pm 2.64$ & -2.429 & 0.020 \\
\hline Night waking & $4.75 \pm 1.48$ & $4.82 \pm 1.74$ & -0.103 & 0.918 \\
\hline Sleep disordered breathing & $3.88 \pm 1.36$ & $3.90 \pm 1.71$ & -0.054 & 0.957 \\
\hline Daytime sleepiness & $14.71 \pm 4.47$ & $14.57 \pm 3.73$ & 0.206 & 0.838 \\
\hline
\end{tabular}


İmrek et al.

Sleep Problems in Children with Conduct Disorder

\begin{tabular}{|l|l|l|l|l|l|}
\hline Table 5. Variables related to DBSAS-DBD-conduct disorders scores for children in linear regression analysis \\
\hline Variables & $\mathbf{B}$ & SEB & $\boldsymbol{\beta}$ & $\mathbf{p}$ & $\mathbf{9 5 \%} \mathrm{Cl}$ \\
\hline Bedtime resistance & 0.715 & 0.145 & 0.891 & $<0.001$ & $0.426-1.004$ \\
\hline Sleep latency & 0.336 & 0.269 & 0.103 & 0.365 & $-0.399-1.070$ \\
\hline Sleep duration & 0.091 & 0.187 & 0.054 & 0.626 & $-0.280-0.463$ \\
\hline Sleep anxiety & 0.151 & 0.146 & 0.132 & -0.305 & $-0.140-0.442$ \\
\hline Night waking & -0.520 & 0.264 & -0.291 & 0.052 & $-1.045-0.005$ \\
\hline Parasomnias & 0.069 & 0.141 & 0.072 & 0.625 & $-0.212-0.350$ \\
\hline Sleep disordered breathing & 0.092 & 0.230 & 0.044 & 0.691 & $-0.366-0.550$ \\
\hline Daytime sleepiness & 0.177 & 0.066 & 0.316 & 0.009 \\
\hline $\mathrm{R}^{2}=0,480, \mathrm{~F}(8.85)=8.894, \mathrm{p}<0.001, \mathrm{Cl}$ : Confidence interval, DBSAS-DBD: DSM-5 based screening and assesment scale for disruptive behavior disorders parent form \\
\hline
\end{tabular}

neurodevelopmental disorders may increase the risk of sleep problems, the results on relative contributions of comorbid ADHD on sleep problems among children with $C D$ have been inconsistent $(9,10)$. Aronen and colleagues reported that children with disruptive behavior disorders (including $C D$ ) who have comorbid ADHD slept significantly less than those without ADHD comorbidity (24). Children with disruptive behavior disorders and ADHD may also display greater resistance at waking in the morning and going to bed at night than those with ADHD alone (9). Those children may also be under elevated risks for sleep-related respiratory problems $(24,25)$. Contrarily, Hvolby et al. (10) reported that the primary driver of sleep problems in oppositional children and those with $C D$ is comorbid ADHD. In partial accordance with those results, we found that ADHD comorbid with CD significantly elevates sleep related anxiety (10). This finding may be due to hyperactive/ impulsive symptoms interfering with sleep or greater familial conflict over sleep times or both. The contribution of those variables as well as the effects of treatment should be elucidated with further, prospective studies.

In regression analyses, bed-time resistance and daytime sleepiness emerged as significant predictors of $C D$ symptom severity. Although the cross-sectional nature of our study precludes hypotheses on causality, this finding may be explained by greater bed-time resistance reducing sleep quantity and quality which in turn may culminate in daytime sleepiness (26). Previous studies also found that greater bed-time resistance was associated with elevated levels of oppositional behaviors and CD symptoms (11).

Our findings should be evaluated within the context of limitations. Firstly, those results are valid for treatment naïve children with $C D$ applying for treatment at the study center and may have limited external validity for clinical samples at other centers or those from the community. Secondly, dependence on parent reports for sleep problems may lead to reporting and recall bias and objective methods of evaluating sleep parameters such as actigraphy/polysomnography may have enriched the results. Third, we did not evaluate for parenting dimensions, family functioning and parental psychopathology which may affect sleep variables. Fourth, mothers of control children had greater levels of education and participation in work force which may have confounded the results. Fifth, over-representation of male participants may have affected the results. Although this male predominance may increase external validity due to $C D$ being more frequent in male children, it may also reduce internal validity due to sample heterogeneity. Sixth, lack of blinding and lack of evaluations for intellectual functioning may also be listed among limitations. We also did not evaluate the effects of treatment on sleep parameters and treatment effects may be examined in future studies. Lastly, peer relationships were evaluated with self-reports which may also be affected by bias.

\section{Conclusion}

Regardless of those limitations, our results suggest that sleep problems in cCDwere elevated compared to healthy control children, and bed-time resistance and daytime sleepiness may predict the severity of CDs. Although cross-sectional design precludes evaluation of causality, it may be prudent to evaluate sleep quality and sleep problems in children with $C D$ at baseline and after initiating treatment in regular intervals.

\section{Ethics}

Ethics Committee Approval: The study was approved by the local research ethics committee (Bolu Abant İzet Baysal University Clinical Trials Ethics Committee, IRB date: 16.03.2020, no: 118).

Informed Consent: Consent form was filled out by all participants.

Peer-review: Internally peer-reviewed.

\section{Authorship Contributions}

Concept: Y.I., G.G.Ö., M.S., B.B., Design: Y.I., G.G.Ö., M.T., Data Collection or Processing: Y.I., M.S., B.B., Analysis or Interpretation: Y.Ö., A.E.T., Literature Search: G.G.Ö., M.S., B.B., M.T., Writing: Y.I., Y.Ö., A.E.T.

Conflict of Interest: No conflict of interest was declared by the authors.

Financial Disclosure: The authors declared that this study received no financial support. 


\section{References}

1. American Psychiatric Association. Diagnostic and Statistical Manual of Mental Disorders. Diagnostic And Statistical Manual Of Mental Disorders. 5th ed. American Psychiatric Association, New YROK, 2013.

2. Fairchild G, Hawes DJ, Frick PJ, Copeland WE, Odgers CL, Franke B, Freitag CM, De Brito SA. Conduct disorder. Nat Rev Dis Primers 2019;5:43.

3. Rivenbark JG, Odgers CL, Caspi A, Harrington H, Hogan S, Houts RM, Poulton R, Moffitt TE. The high societal costs of childhood conduct problems: evidence from administrative records up to age 38 in a longitudinal birth cohort. J Child Psychol Psychiatry 2018;59:703-10.

4. Halliburton AE, Ridenour TA, White BA, Deater-Deckard K. Clinically differentiating life-course-persistent and adolescence-limited conduct problems: Is age-of-onset really enough? J Appl Dev Psychol 2017; 52:34-45.

5. Franco P, Putois B, Guyon A, Raoux A, Papadopoulou M, GuignardPerret A, Bat-Pitault F, Hartley S, Plancoulaine S. Sleep during development: sex and gender differences. Sleep Med Rev 2020;51:101276.

6. Newton AT, Honaker SM, Reid GJ. Risk and protective factors and processes for behavioral sleep problems among preschool and early school-aged children: a systematic review. Sleep Med Rev 2020;52:101303.

7. Meltzer LJ. Future Directions in Sleep and Developmental Psychopathology. J Clin Child Adolesc Psychol 2017;46:295-301.

8. Gregory AM, Sadeh A. Annual Research Review: Sleep problems in childhood psychiatric disorders - A review of the latest science. I Child Psychol Psychiatry Allied Discip 2016;57:296-317.

9. Becker SP. ADHD and sleep: recent advances and future directions. Curr Opin Psychol 2020;34:50-6.

10. Hvolby A, Christensen J, Gasse C, Dalsgaard S, Dreier JW. Cumulative incidence and relative risk of sleep problems among children and adolescents with newly diagnosed neurodevelopmental disorders: A nationwide register-based study. J Sleep Res 2021;30:e13122. doi: $10.1111 /$ jsr.13122.

11. Coto J, Garcia A, Hart KC, Graziano PA. Associations between disruptive behavior problems, parenting factors, and sleep problems among young children. J Dev Behav Pediatr 2018;39:610-20.

12. Sosnowski DW, Kliewer W, Lepore SJ. The role of sleep in the relationship between victimization and externalizing problems in adolescents. J Youth Adolesc 2016;45:1744-54.

13. Carvalho F, Vilaça J, Carvalho AL, Pontes T, Carvalho S. Sleep quality and bullying - prevalence in a cohort of Portuguese students. Int J Adolesc
Med Health. 2020 Jun 6:/j/ijamh.ahead-of-print/ijamh-2020-0018/ ijamh-2020-0018.xml. doi: 10.1515/ijamh-2020-0018. Epub ahead of print

14. Short MA, Weber N. Sleep duration and risk-taking in adolescents: A systematic review and meta-analysis. Sleep Med Rev 2018;41:185-96.

15. Backman H, Laajasalo T, Saukkonen S, Salmi V, Kivivuori J, Aronen ET. Are qualitative and quantitative sleep problems associated with delinquency when controlling for psychopathic features and parental supervision? J Sleep Res 2015;24:543-8.

16. Kaufman J, Birmaher B, Brent D, Rao U, Flynn C, Moreci P, Williamson $D$, Ryan N. Schedule for affective disorders and schizophrenia for school-age children-present and lifetime version (K-SADS-PL): Initial reliability and validity data. I Am Acad Child Adolesc Psychiatry 1997;36:980-8.

17. Gökler B, Ünal F, Pehlivantürk B. Reliability and Validity of schedule for affective disorders and schizophrenia for school age childrenpresent and lifetime version-Turkish version (K-SADS-PL-T). Turk J Child Adolesc Ment Health 2004;11:109-16.

18. Turgay A. The DSM-IV Based child and adolescent behavior rating scale. Ontario, Canada, 1995.

19. Ercan ES, Amado S, Somer O, Cikoglu S. Development of a test battery for attention deficit hyperactivity and disruptive behavior disorders. Turk J Child Adolesc Ment Heal 2001;132-44.

20. Owens JA, Spirito A, McGuinn M. The Children's Sleep Habits Questionnaire (CSHQ): psychometric properties of a survey Instrument for school-aged children. Sleep 2000;23:1-9.

21. Fiş NP, Arman A, Ay P, Topuzoğlu A, Güler As, Gökçe-Imren S, Ersu $\mathrm{R}$, Berkem M. Çocuk uyku alışkanlıkları anketinin türkçe geçerliliği ve güvenilirliği. Anadolu Psikiyatr Derg 2010;11:151-60.

22. Vazsonyi AT, Ksinan Jiskrova G, Ksinan AJ. Sleep, low self-control, and deviance: direct and indirect links across immigrant groups and socioeconomic strata. J Adolesc 2018;68:40-9.

23. Gradisar M, Gregory AM, Tikotzky L. Is sleep the red flag to psychopathology's bull? J Child Psychol Psychiatry Allied Discip 2020;61:1055-7.

24. Aronen ET, Lampenius T, Fontell T, Simola P. Sleep in children with disruptive behavioral disorders. Behav Sleep Med 2014;12:373-88.

25. Constantin E, Low NCP, Dugas E, Karp I, O'Loughlin J. Association between childhood sleep-disordered breathing and disruptive behavior disorders in childhood and adolescence. Behav Sleep Med 2015;13:442-54.

26. Wilsmore BR, Grunstein RR, Fransen M, Woodward M, Norton R, Ameratunga S. Sleep habits, insomnia, and daytime sleepiness in a large and healthy community-based sample of New Zealanders. I Clin Sleep Med 2013;9:559-66. 